\title{
IDENTIFYING BARRIERS TO IMPLEMENTATION OF LOCAL TRANSPORT POLICY: AN ANALYSIS OF BUS POLICY IN GREAT BRITAIN
}

\author{
Clare McTigue, ${ }^{1}$ Jason Monios ${ }^{2}$ and Tom Rye ${ }^{1}$ \\ ${ }^{1}$ Transport Research Institute, Edinburgh Napier University \\ Merchiston Campus, Edinburgh, EH10 5DT, United Kingdom \\ ${ }^{2}$ Kedge Business School, Domaine de Luminy, \\ Rue Antoine Bourdelle, 13009 Marseille, France
}

\begin{abstract}
This research aims to identify barriers to the implementation of local transport policy by exploring bus policy implementation in Great Britain. The methodology is based on an online survey with $56 \%$ of local authorities and follow-up interviews with 10 of those officers, analysed via a ten-point hybrid theory. The greatest challenges faced by local authorities included the availability of financial and staff resources, the existence of a clear policy document and inter-organisational communication. The relationship between setting policy objectives, selecting suitable measures to achieve those objectives, and setting and monitoring targets was identified as key to successful policy implementation.
\end{abstract}

Key words: transport policy; implementation; bus 


\section{Introduction}

Buses are the most frequently used and most accessible mode of public transport in Great Britain. They are essential for delivering economic, social, and health benefits. In particular, bus services enable people to get from place to place and provide important access to work, health, and education. In some instances, bus services are the only available mode of transport for those without automobile access. Bus networks are also estimated to generate substantial economic benefits by providing "access to opportunities, reducing pollution and accidents and improving productivity" (Urban Transport Group, 2016). The impact of bus patronage and bus mileage are the key aspects of providing an effective bus network.

Statistics released by Transport Scotland (2016), the Welsh Government (2016) and the UK DfT (2016) show a steady decline in bus mileage across Great Britain outside of London. In Scotland, vehicle kilometres have fallen by $12 \%$ over the past five years, while in Wales, the number of vehicle kilometres travelled by subsidised services has fallen by around a third since 2009-10 (Welsh Government, 2016). In England as a whole, mileage supported by local authorities decreased by $0.6 \%$ when compared with the previous year. According to DfT (2016), there was a 10\% reduction in local authority supported services in England outside London, while commercial mileage increased by $1.4 \%$. Furthermore, over the last decade in England outside of London, local authority supported mileage has decreased by 55 million miles, and commercial mileage has increased by 13 million miles. This is particularly evident where the percentage of bus mileage on supported services has decreased from $22 \%$ in 200405 to $17 \%$ in $2014-15$.

Similar to bus mileage, there has also been a decline in bus usage, which has a damaging effect on the bus network. Additional statistics released by Transport Scotland (2016), the Welsh Government (2016), and the UK DfT (2016) show a steady decline in bus patronage across Great Britain outside of London. This is particularly noticeable where public transport patronage has more than halved from peak levels in the early 1950s (McConville, 1997). In Scotland, around 414 million passenger journeys were made by bus in 2014-15, a decrease of $2 \%$ on 2013-14 and a 15\% fall from the latest peak in 2007-08. In Wales, around 101 million passenger journeys were made by bus in 2014-15; however, the number of journeys decreased over the last six years. In England outside of London, around 2.28 billion passenger journeys were made by bus in 2014-15. Again, there has been a gradual decline in passenger numbers in recent years including a decrease of $1.3 \%$ on 2013-14. Figure 1 summarises the overall trends 
in local bus journeys by country, giving a clear indication that bus usage in London has risen as bus usage in England outside of London and in Scotland, and Wales has declined.

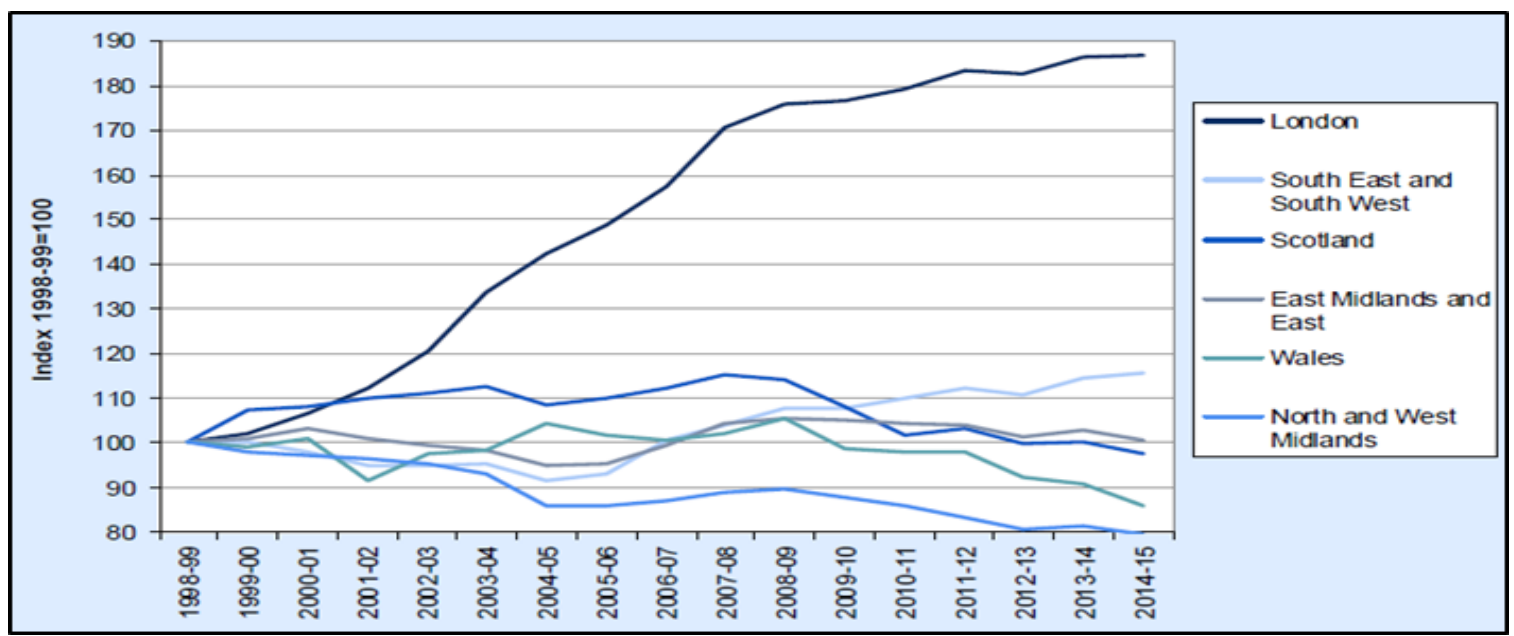

Figure 1: Local bus journeys by country and groupings of regions 1998-99 to 2014-15

Source: DfT (2016)

A decrease in bus patronage and bus mileage has a damaging effect on the delivery of bus services across the UK. As well as having a negative impact on economic, social, and health benefits, quality of life suffers due to a lack of physical access to jobs, health, education, and amenities (Banister, 2000). To overcome the problems associated with the decline in bus patronage and bus mileage, local transport policies are needed. In particular, local bus policies are vital to the successful provision of local bus service and infrastructure to support the needs of current bus users and to provide an attractive alternative to automobile users. In this research, bus policy means a set of objectives, targets, and related measures, normally developed by the local or regional authority (municipality) that together, if followed and implemented, will bring about improvements in local bus services to support wider transport policy objectives. A bus policy measure is something that is implemented, such as higher quality buses or bus priority lanes on the street. Of course, certain measures, such as new bus shelters, may be relatively easy for a municipality to deliver, since it has direct control over this infrastructure. Measures whose delivery is dependent wholly or in part on other actors, such as bus operators or information providers or the police, can be more difficult to implement.

Under the regulatory framework for local bus services in Great Britain outside London, bus operators are almost all private for-profit companies, and all of them are free to set routes, fares, and timetables as they see fit. This situation is unusual in developed countries; the findings of 
this research are nonetheless relevant to other regulatory environments. Whenever responsibilities for service planning, strategy, operations, and infrastructure, for example, are split between different organisations (as is the case in most Nordic countries), or even between different parts of the same organisation (the case in major cities in Slovenia, for example), there is scope for strategic policy objectives not to be realised.

Currently, bus policies are included in the Local Transport Plans (LTPs) and Local Transport Strategies (LTSs) of local authorities in England and Scotland, respectively. The first round of these LTPs were submitted by English local authorities in 2001, while LTSs were submitted by Scottish local authorities in 2000. The introduction of the LTS by Scottish local authorities was voluntary compared to LTPs in England which were made a statutory requirement by the 2000 Transport Act (although this requirement was repealed in 2017). The LTPs and LTSs support local authorities to help improve their current bus services (as well as other modes of transport such as walking and cycling, and policy areas such as road safety) and achieve a modal shift from the automobile. According to Scottish Government (2005), local bus networks are more likely to be successful if there is "a close working partnership between the local authority and the bus operators." These partnerships are vital to overcoming key barriers to successful bus services in terms of "traffic demand management," "congestion reduction," "bus priority measures," "the provision of accessible buses," "simplified fare structures," and "route branding."

Guidance on LTPs associated with the 2000 Act also required English authorities to produce annual monitoring reports to show how their LTPs were progressing. At the end of the first five-year LTP period in 2006, a lengthy Delivery Report was produced to show what had and had not been implemented, and why, over the previous five years. By contrast, Scottish authorities had no statutory requirement to monitor the progress of their LTS. However, the Local Transport Act 2008 in England removed this system of close monitoring of LTPs. Furthermore, the act also removed the requirement to produce a separate bus strategy. With the abolition of annual monitoring reports and a separate bus strategy, there are currently no statutory requirements in place for local authorities to monitor the performance of local bus services in the UK.

Several studies have highlighted the importance of monitoring LTPs and LTSs. Spear and Lightowler (2005) carried out a study on delivering LTSs in Scotland at the end of the first 
five-year Scottish LTS period. They summarised lessons learned from the English LTPs which would be useful for preparing and monitoring future LTSs in Scotland. However, they suggested that the absence of a systematic LTS annual reporting process made it more difficult to assess how Scottish authorities have used their LTSs to deliver improvements on the ground, contribute to their objectives or offer value for money for the resources provided. Furthermore, the absence of LTS annual monitoring also meant the problems with LTSs could not be addressed. Another study by McTigue et al. (2016) compared the LTP 2001-2006 and the LTP Delivery Report for three English cities in order to obtain an insight into the importance of reporting in the implementation of local bus policy. A lack of policy resources was identified as a key barrier to implementation, while key aspects of success, such as communication and support within the organisation, were not being documented by local authorities. This, in turn, limited the ability of local authorities to monitor the reasons for successful implementation or lack thereof.

The aim of this research is to identify barriers to implementation of bus policies by local authorities in Great Britain, which can then be generalised both to bus policy in other countries and more broadly to local transport policy.

\section{Literature review}

\subsection{Bus policy in Great Britain}

Although no studies specifically address the implementation process for bus policies at the local level, several studies have explored bus deregulation in Great Britain and its impact on the sector. White $(1995,1997)$ examined the short-term impact of deregulation and found that while the cost per kilometre operated had fallen, patronage had also fallen and profitability only remained marginal. Another study by White (2010) examined the conflict between competition policy and the wider role of the local bus industry in Great Britain since deregulation, exploring issues such as the removal of previous restrictions on routes, service levels and fares and a reversal of the previous emphasis on coordination of services.

A study by Preston and Almutairi (2013a) examined bus deregulation and the long-term impact it had on the sector, using demand, cost, and fares models. They found that London (where deregulation is not in place) shows a positive pattern of welfare gains; however, passengers received fewer benefits when the subsidy was reduced. By comparison, there is a negative pattern with welfare impacts outside London, and the study concludes a regulated bus service 
similar to that in London would be more appropriate. Preston and Almutairi (2013b) reevaluated this position and found a considerable welfare loss. Another study by Preston (2016) looked at the impact of bus deregulation in Wales in the mid-1980s, showing a decrease in bus trips and vehicle mileage, a rise in fares and operating costs, and a decrease in subsidy. The study concludes that for urban parts of Wales, the implementation of a Bus Rapid Transit scheme to complement the existing rail network would help improve the barriers associated with bus deregulation. For rural areas, the study indicates that a lack of funding has prevented the development of more flexible public transport services and therefore proposes the implementation of other reforms such as Quality Contracts, Quality Partnerships, and Community Partnerships.

Van de Velde and Wallis (2013) examined the longer term impact of deregulation in Great Britain and New Zealand and partial deregulation in Sweden. While they suggest there is no clear-cut evidence yet on what is the best deregulated regime, their research highlights some success in terms of patronage growth at a local level. This success is dependent on the coexistence of a favourable public transport policy that places limits on automobile use by means of parking charges, pedestrian-only zones, and extensive park-and-ride facilities. Finally, a study by Van de Velde \& Augustin (2014) suggests that where deregulation is sustained as a regime, and performance improvement depends on avoiding repetition the simplistic and dogmatic interpretations that dominated earlier implementations. They believed a more balanced view would need to be developed based on theoretical considerations and a thorough review of experience, in terms of performance itself and the mechanisms that lead to performance. 


\subsection{Transport policy implementation}

Other studies have examined various modes of transport policy to identify the barriers to developing and implementing sustainable transport policies. These studies include mixed datacollection methods such as questionnaires, telephone interviews, and face-to-face interviews with key individuals who are knowledgeable or experienced with dealing with transport policy. For example, Lindholm and Blinge (2014) assessed the knowledge and awareness of sustainable urban freight transport among Swedish local authority policy planners. A questionnaire was completed by the planners, and the results identified a "lack of coordination, sufficient resources and effective knowledge transfer among stakeholders in urban freight transport" as key barriers related to freight policy implementation. Similarly, Ballantyne et al. (2013) carried out 74 interviews with local authorities and freight stakeholders in northern Europe to examine a variety of cities on urban freight transport, and their inclusion of urban freight stakeholders in local authority transport planning. The study concluded that the issues local authorities face also occur in other countries and are "not unique to one country or specific category." Therefore a generic policy framework is recommended to help overcome the barriers associated with the interaction between local authorities and freight stakeholders.

Some scholars have also explored the barriers related to developing and implementing incentives related to climate policy. Gossling et al. (2016, p.83) carried out interviews with 12 European policy officers on the objectives of climate policy in the transport sector. The study identified key barriers associated with emissions include a "lack of political leadership," "resistance from member states," "favouring of economic growth over cuts in greenhouse gas emissions," "pressure from industry and lobby groups," "policy implementation delays," "insufficient forecasting and monitoring tools," and "overreliance on technologies." Another study on climate policy by Argyrioua et al. (2012, p.87) explored the progress of UK local authorities and the barriers they face in developing and implementing climate policy initiatives. The main barriers towards these policy initiatives include a "lack of time, resources and difficulties in engaging with the wider community." They concluded that local authorities need to exchange knowledge on climate change and that the effectiveness of these policies can be monitored more closely through UK sub-national statistics data.

Several studies have examined the role of policy implementation in travel plan policies. For example, De Gruyter et al. (2015, p.34) carried out a series of interviews with 30 transport 
representatives, primarily from industries in Australia, to develop new initiatives to improve travel plans for new residential developments. The key barriers identified with implementing travel plans were a "lack of enforcement," "uncertainty over implementation responsibilities," and a "general lack of ownership." Similarly, a study by Ison and Rye (2003, p. 232) assessed travel plans and road user charging with respect to a theoretical framework developed by Gunn (1978) and found that this framework fails to cover all the essentials for successful policy implementation such as "monitoring," "a policy champion," "political stability," "trust in terms of the parties' involved," "consideration of public relations," and "careful timing." Gaffron (2003) carried out a questionnaire survey with UK local transport authorities on issues related to walking and cycling. The three most important factors hindering policy implementation included a "lack of funding," "lack of staff," and "lack of time."

These studies show that barriers related to policy implementation at a local level are not restricted to one category and indeed are similar across different transport policy sectors and modes such as freight, climate, travel plans, road user charging, walking, and cycling. These studies underscore the barriers associated with developing and implementing transport policies and the importance of developing mechanisms to prevent these barriers from arising. The next section explores the theoretical approaches to policy implementation meant to overcome these barriers.

\subsection{Theoretical approaches to policy implementation}

The study of policy implementation evolved during the late 1960s, and numerous scholars have attempted to develop policy implementation models and frameworks to address the gaps that often occur between policy decision intent and implementation outcome or policy performance. These frameworks are used to determine what makes a policy and its subsequent implementation successful. The scholarship on policy implementation can be divided into three distinct theoretical approaches. The theoretical framework used here draws on key aspects of the top-down and bottom-up frameworks as well as hybrid frameworks.

Top-down frameworks suggest that centralised policymakers should be as clear as possible with their goals, minimize the number of bureaucrats on which a policy depends, and limit necessary change (Matland, 1995). Four key theorists embraced this approach: Pressman and Wildavsky (1973), Van Meter and Van Horn (1975), Gunn (1978), and Sabatier and 
Mazmanian (1981). Bottom-up frameworks "emphasise target groups and service deliverers, arguing that policy is made at the local level" (Matland, 1995: 146). Five key theorists embraced this approach: Lipsky (1971, 1980), Hjern et al. (1978), Elmore (1980), Rein (1983), and Grindle and Thomas (1990).

Hybrid or synthesis frameworks incorporate elements of both top-down and bottom-up approaches, building on their respective conceptual strengths. This research builds on the hybrid framework developed by McTigue et al. (2016) (Table 1), which consists of a ten-point analytical matrix based on a synthesis of the frameworks devised by the theorists mentioned above. It also includes a synthesis of theoretical studies carried out by Cerna (2013) and Wickramasinghe (2016). The hybrid theory is used to analyse the results of online surveys and telephone interviews following the study carried out by McTigue et al. (2016), which used the hybrid theory to analyse LTPs and LTP Delivery Reports for three English cities. This research takes a similar approach with the aim of helping local authority staff and policymakers avoid barriers to effective policy development and implementation.

The first part of the framework highlights the importance of setting policy objectives. Objectives should be placed in a written policy document that acts as an umbrella for the policy process and specifies targets, measures, and monitoring mechanisms. Annual review of these documents is beneficial to see where policy is being implemented successfully or where barriers are undermining the implementation process. As previously mentioned, annual monitoring reports and a separate bus strategy are no longer statutory requirements for local authorities in Great Britain.

The second part of the theory identifies resources, including financial support, as an important factor for successful implementation. However, where resources are limited, it is necessary to maximise their use. One solution for maximising resources is the development of a business plan, which sets out clear expectations and realistic time scales, and limits resource waste.

The next part of the theory looks at internal factors that can have an impact on policy implementation. These include inter-organisation support and communication (e.g., staff training and supervision), characteristics of the organisation (e.g., size, competency, and workload of staff), and bureaucratic power of members within the organisation. The theory then looks at external factors that can have an impact on policy implementation. These include 
economic (e.g., the impact of globalisation on the transport sector), social (e.g., demographic change), and political (e.g., the stability of local governments) factors. Other external factors include opposition, conflict, and ambiguities (e.g., public opposition, political power, local and national elections, conflicts between neighbouring authorities over budgets, bus wars, and open access to bus operating data).

The final part of the framework considers factors with both internal and external elements, including policy remodelling (e.g., changes during the design stage that may cause unnecessary delays and over-spending), collaboration and interaction between those involved in the policy process (e.g., collaboration between local authority and bus operators), and policy champions (e.g., advocates who are responsible, competent, and motivated to see the policy follow through from beginning to end). Table 1 provides a summary of the hybrid theory used to analyse the data collected in the research.

Table 1: Policy implementation recommendations

\begin{tabular}{|l|l|l|}
\hline 1 & Policy document & $\begin{array}{l}\text { A written bus policy document should be in place, } \\
\text { showing clear links between policy objectives, measures, } \\
\text { and the setting and monitoring of targets. }\end{array}$ \\
\hline 2 & Availability of resources & $\begin{array}{l}\text { Resources such as financial support are important; where } \\
\text { resources are limited, it is necessary to maximise the use } \\
\text { of available resources. }\end{array}$ \\
\hline 3 & $\begin{array}{l}\text { Inter-organisation support } \\
\text { and communication }\end{array}$ & $\begin{array}{l}\text { Policy staff needs relevant training, supervision, and } \\
\text { support within their organisation when dealing with } \\
\text { complex policy issues. }\end{array}$ \\
\hline 4 & $\begin{array}{l}\text { Characteristics of the } \\
\text { organisation }\end{array}$ & $\begin{array}{l}\text { Formal structural features of the organisations and } \\
\text { informal attributes of their personnel (including size, } \\
\text { competency, and workload of staff) should not constrain } \\
\text { the policy implementation. }\end{array}$ \\
\hline 5 & $\begin{array}{l}\text { Economic, social and political } \\
\text { environments }\end{array}$ & $\begin{array}{l}\text { Current and future economic, social and political } \\
\text { environments play an important role in the outcome of } \\
\text { the policy process. }\end{array}$ \\
\hline 6 & $\begin{array}{l}\text { Policy champions } \\
\text { policy implementation should not be restricted to one } \\
\text { policy champion and instead needs several policy } \\
\text { champions who are responsible, competent and } \\
\text { motivated to see the policy through from beginning to } \\
\text { end. }\end{array}$ \\
\hline
\end{tabular}




\begin{tabular}{|l|l|l|}
\hline 7 & Bureaucratic power & $\begin{array}{l}\text { Hierarchical control in an organisation is important; } \\
\text { hierarchical power should not be used to overrule policy } \\
\text { decisions by other members of the organisation. }\end{array}$ \\
\hline 8 & $\begin{array}{l}\text { Collaboration and interaction } \\
\text { between those involved in the } \\
\text { policy process }\end{array}$ & $\begin{array}{l}\text { Collaboration and interaction are necessary between key } \\
\text { actors involved in the policy process, including } \\
\text { policymakers, local authority staff, local and national } \\
\text { governing bodies, regional transport partnerships, bus } \\
\text { operators and transport practitioners working within the } \\
\text { transport field. }\end{array}$ \\
\hline 9 & Policy remodelling & $\begin{array}{l}\text { Limited changes to the policy should occur from the } \\
\text { design stage right through to the implementation stage. }\end{array}$ \\
\hline 10 & $\begin{array}{l}\text { Opposition, conflict, and } \\
\text { ambiguities }\end{array}$ & $\begin{array}{l}\text { Opposition, conflict, and ambiguities are inevitable } \\
\text { including public opposition, political power, local and } \\
\text { national elections, conflicts between neighbouring } \\
\text { authorities over budgets, bus wars, and open access to bus } \\
\text { operating data. }\end{array}$ \\
\hline
\end{tabular}

* Based on the hybrid theory of McTigue et al. (2016)

\section{Methodology}

A mixed data collection method of online surveys and telephone interviews was applied to evaluate the effectiveness of bus policy implementation in Great Britain. According to Marshall and Rossman (1999), this methodological approach enhances the generalisation of research findings. A self-completion questionnaire survey was designed using an online survey software and then administered via email to public transport officers in Great Britain, outside of London. All 143 Local authorities were contacted to identify suitable participants for the survey. The survey consisted of 16 questions ranging from dichotomous, multiple choice, rank order scaling, and rate scaling questions.

Statistical tests were used to help interpret the results of the survey, following the methodology of Gaffron (2003) who performed a similar survey of cycling policies in local authorities in the UK. This study used a $2 \times 2$ cross-tabulation, and chi-square analysis (Table 7 ) to determine whether the policy objectives and measures are statistically independent. The results of these statistical tests were only considered significant if the probability $p$ of making the recorded observation by chance was less than $5 \%(p<0.05)$.

In addition, semi-structured telephone interviews were conducted with ten of the public transport officers from the online survey to elicit a deeper understanding of the results. These 
interviewees were self-selected based on positive responses to an invitation in the survey. This second research method enabled in-depth discussion to achieve a full understanding of the issues raised in the survey. The telephone interviews consisted of 16 open-ended questions and were recorded and transcribed. Both sets of questions were structured under five policy analysis themes used to organize the findings of this study: policy documentation; policy responsibility; policy targets; performance monitoring; and implementation barriers. The analysis was based on the application of the ten-point framework of the hybrid theory to both sets of data. Differences observed in some responses between the survey and the interviews suggests evidence of response bias in the former, in that some respondents were more inclined to provide what they perceived to be the "desirable" or "appropriate" response to the questionnaire whereas in interviews the personal rapport developed enabled a great deal more frankness by respondents. This difference may be the cause of some of the apparent contradictions between the questionnaire and interview results discussed in the relevant following sections (for example, with respect to the reported importance of relationships between operators and local authority staff).

\section{Results}

\subsection{Online survey results}

76 Local Authorities provided their council name while four local authorities remained anonymous. The highest response rate was from combined local authorities (57\%) while the lowest response rate was from Welsh local authorities (41\%). There was reasonable variation of local authority areas with respect to geographical locations in the UK. Table 2 provides a summary of the returned surveys based on location: 
Table 2: Returned surveys and location

\begin{tabular}{|c|c|c|}
\hline Location & $\begin{array}{c}\text { No. of Returned } \\
\text { Surveys }\end{array}$ & $\begin{array}{c}\text { Response Rate for } \\
\text { Location }\end{array}$ \\
\hline Welsh County Councils & $9 / 22$ & $41 \%$ \\
\hline Scottish County Councils & $18 / 32$ & $56 \%$ \\
\hline $\begin{array}{c}\text { English Unitary authorities plus the Isles } \\
\text { of Scilly }\end{array}$ & $30 / 55$ & $53 \%$ \\
\hline English County Councils & $15 / 27$ & $56 \%$ \\
\hline English Combined Local Authorities & $4 / 7$ & $57 \%$ \\
\hline Anonymous & 4 & N/A \\
\hline Total & $\mathbf{8 0 / 1 4 3}$ & $\mathbf{5 6 \%}$ \\
\hline
\end{tabular}

To determine the rural-urban classification for the UK local authorities used in this study, this research follows the guidelines provided by Defra Rural Statistics (2017), which defines ruralurban classification for local authority districts and unitary authorities in England and Wales. Authorities are classified as predominantly rural, significantly rural, or predominantly urban. A three-way classification was created for this research for ease of reference because the Scottish Government has a different system than England and Wales. Although the thresholds for England, Wales, and Scotland differ, any settlement in the U.K. with a population greater than 10,000 people is defined as urban. However, settlements with a population between 3,500 and 10,000 people are defined differently (Pateman, 2011). For the purposes of this research, these thresholds are aggregated to identity regions as predominantly urban, urban with substantial rural, and predominantly rural in accordance with Defra Rural Statistics (2017). Table 3 shows the completed surveys by area and classification. 
Table 3: Completed surveys in regions vs local authority type

\begin{tabular}{|l|c|c|c|c|c|c|c|}
\hline \multirow{2}{*}{ Region } & \multicolumn{7}{|c|}{ Area } \\
\cline { 2 - 8 } & Wales & Scotland & $\begin{array}{c}\text { England } \\
\text { Unitary }\end{array}$ & $\begin{array}{c}\text { England } \\
\text { County }\end{array}$ & $\begin{array}{c}\text { England } \\
\text { Combined }\end{array}$ & Anonymous & Total \\
\hline $\begin{array}{l}\text { Predominantly } \\
\text { Urban }\end{array}$ & 2 & 13 & 19 & 1 & 3 & 0 & $\mathbf{3 8}$ \\
\hline $\begin{array}{l}\text { Predominantly } \\
\text { Rural }\end{array}$ & 4 & 3 & 6 & 5 & 0 & 0 & $\mathbf{1 8}$ \\
\hline $\begin{array}{l}\text { Substantially } \\
\text { Rural }\end{array}$ & 3 & 2 & 5 & 9 & 1 & 0 & $\mathbf{2 0}$ \\
\hline Anonymous & 0 & 0 & 0 & 0 & 0 & 4 & $\mathbf{4}$ \\
\hline Total & $\mathbf{9}$ & $\mathbf{1 8}$ & $\mathbf{3 0}$ & $\mathbf{1 5}$ & $\mathbf{4}$ & $\mathbf{4}$ & $\mathbf{8 0}$ \\
\hline
\end{tabular}

\subsubsection{Policy documentation}

This series of questions asked the officers about their current bus policy, key objectives, and the measures required to achieve these objectives. The first question in this section asked the officers how long their council had a written local bus policy in place. Table 4 indicates that $73.9 \%$ of councils had a written bus policy in place, almost half of them for 11 or more years. $1.3 \%$ said they were in the process of developing a policy; $17.6 \%$ said they do not have a local bus policy written down in a single document or do not have any local bus policy. The lack of a local bus policy document is most likely linked to the abolition of the requirement for a separate bus strategy in the 2008 Local Transport Act.

Although there was no statistical association between the urban or rural location of local authorities and the number of years they have had a written local bus policy in place, the findings in Table 4 indicate that 16\% of local authorities "don't have a local bus policy written down in a single document." This could be associated with both the size and region of the local authority. It may be that local authorities in rural areas find it more appropriate and simpler to have a single document due to being smaller in size or to the extent of bus provision in the area, in comparison to larger urban authorities that have more bus provision and improvements to consider. ${ }^{1}$

\footnotetext{
${ }^{1}$ However, because the bus policy documents of every responding authority were not received, it is not possible for the authors to be certain that this is the case for every authority.
} 
Table 4: Number of years written bus policy document in place

\begin{tabular}{|l|c|c|}
\hline \multicolumn{1}{|c|}{ Answer } & Count & $\%$ \\
\hline Less than 1 year & 1 & $1 \%$ \\
\hline 1 to 5 years & 11 & $14 \%$ \\
\hline 6 to 10 years & 8 & $10 \%$ \\
\hline 11 or more years & 39 & $49 \%$ \\
\hline $\begin{array}{l}\text { We don't have a local bus policy written down in a single } \\
\text { document }- \text { it is more a collection of actions and policies }\end{array}$ & 13 & $16 \%$ \\
\hline We don't have any kind of local bus policy & 1 & $1 \%$ \\
\hline We are in the process of developing one & 1 & $1 \%$ \\
\hline Not answered & 6 & $8 \%$ \\
\hline
\end{tabular}

The next question asked the officers to identify their bus policy objectives. Of the officers who answered this question, 93\% indicated councils are setting objectives. Table 5 shows that between 51.3 to $88.8 \%$ of officers included the listed policy objectives, which demonstrates that councils recognize the importance of stated bus policy to overall transport objectives.

Table 5: Bus policy objectives

\begin{tabular}{|l|c|c|}
\hline \multicolumn{1}{|c|}{ Answer } & Count & $\%$ \\
\hline To promote equal access to transport & 71 & $89 \%$ \\
\hline $\begin{array}{l}\text { To improve environmental quality and reduce the effects of transport } \\
\text { pollution on air quality }\end{array}$ & 63 & $79 \%$ \\
\hline To help the transport system operate more efficiently & 60 & $75 \%$ \\
\hline $\begin{array}{l}\text { To provide opportunities for fostering a strong, competitive } \\
\text { economy and sustainable economic growth }\end{array}$ & 57 & $71 \%$ \\
\hline $\begin{array}{l}\text { To maintain the transport infrastructure to standards that allow safe } \\
\text { and efficient movement of people and goods }\end{array}$ & 56 & $70 \%$ \\
\hline $\begin{array}{l}\text { To contribute to national and international efforts to reduce } \\
\text { transport's contribution to overall greenhouse gas emissions }\end{array}$ & 47 & $59 \%$ \\
\hline $\begin{array}{l}\text { To improve safety, security, and health, and in particular to cut the } \\
\text { number and severity of road casualties }\end{array}$ & 41 & $51 \%$ \\
\hline
\end{tabular}

The last question in this section asked the officers to select from a list provided the stage at which bus measures are in their city, in order to judge the level of success of implementation of different types of measure (Table 6). Successful measures included the provision of bus information, bus shelters and improved pedestrian access to stops. RTPI is also becoming more successful where $25 \%$ have considered this and will implement it in the future. Similarly, $21.3 \%$ said they will also implement multi-operator integrated tickets and review current bus lane networks and ensure they are effective, legible and enforced. However, some measures 
appeared to be less successful including tickets which can be bought before boarding buses, personal security (CCTV, lighting) and new bus lanes. The least successful measure (maximum fares) could arguably be a result of its applicability to the officers interviewed whereby maximum fares can only be set by English and Welsh councils if they have a statutory quality partnership in place (under the 2008 Local Transport Act). In Scotland, there is no legal possibility for councils to set maximum fares.

Table 6: Bus policy measures

\begin{tabular}{|l|c|c|c|c|}
\hline \multicolumn{1}{|c|}{ Answer } & $\begin{array}{c}\text { We have } \\
\text { implemented } \\
\text { this }\end{array}$ & $\begin{array}{c}\text { We considered } \\
\text { this, and we } \\
\text { will implement } \\
\text { in the future }\end{array}$ & $\begin{array}{c}\text { We considered } \\
\text { this, but we } \\
\text { will not } \\
\text { implement it }\end{array}$ & $\begin{array}{c}\text { We will } \\
\text { look at } \\
\text { this in } \\
\text { the } \\
\text { future }\end{array}$ \\
\hline $\begin{array}{l}\text { Bus Information }- \\
\text { timetables and bus } \\
\text { stop flags }\end{array}$ & $72(90 \%)$ & $4(5 \%)$ & $0(0 \%)$ \\
\hline Shelters & $67(84 \%)$ & $4(5 \%)$ & $2(3 \%)$ & $3(4 \%)$ \\
\hline $\begin{array}{l}\text { Improved pedestrian } \\
\text { access to stops }\end{array}$ & $64(80 \%)$ & $11(14 \%)$ & $1(1 \%)$ & $4(5 \%)$ \\
\hline $\begin{array}{l}\text { Real-time passenger } \\
\text { information }\end{array}$ & $52(65 \%)$ & $20(25 \%)$ & $4(5 \%)$ & $3(4 \%)$ \\
\hline $\begin{array}{l}\text { Multi-operator } \\
\text { integrated tickets }\end{array}$ & $40(50 \%)$ & $17(21 \%)$ & $6(8 \%)$ & $11(14 \%)$ \\
\hline $\begin{array}{l}\text { Reviewing current } \\
\text { bus lane network and } \\
\text { its operation to } \\
\text { ensure it is effective, } \\
\text { legible and enforced }\end{array}$ & $29(36 \%)$ & $17(21 \%)$ & $10(13 \%)$ & $15(19 \%)$ \\
\hline $\begin{array}{l}\text { Tickets which can be } \\
\text { bought before } \\
\text { boarding buses }\end{array}$ & $29(36 \%)$ & $10(13 \%)$ & $8(10 \%)$ & $21(26 \%)$ \\
\hline $\begin{array}{l}\text { Personal security } \\
\text { (CCTV, lighting) }\end{array}$ & $28(35 \%)$ & $13(16 \%)$ & $13(16 \%)$ & $16(20 \%)$ \\
\hline $\begin{array}{l}\text { New bus lanes } \\
\text { Maximum fares }\end{array}$ & $26(33 \%)$ & $16(20 \%)$ & & $18(23 \%)$ \\
\hline
\end{tabular}

Table 7 shows the correlation between bus policy objectives (Table 4) and bus policy measures implemented to achieve those objectives (Table 5). These findings reveal that, regardless of the policy objectives selected, the same policy measures were the most popular. With only a few 
minor exceptions, the order of popularity of measures was the same when cross-referenced against all of the policy objectives. This suggests that these measures were not chosen to meet specific policy objectives but for other reasons such as contributing towards several objectives simultaneously or being easier or cheaper to implement. For example, bus information is likely to be easier to implement due to the duties and powers that local authorities have in this area under both the 1985 and 2000 Transport Acts. In comparison to this, control over maximum fares is something much more difficult to implement due to limited legal powers for local authorities in this area, as also outlined in Section 4.1.1.

Table 7: Cross-tabulation of bus policy objectives and measures

\begin{tabular}{|c|c|c|c|c|c|c|c|c|c|c|}
\hline \multirow[b]{2}{*}{ Objective } & \multicolumn{10}{|c|}{ Measures Implemented } \\
\hline & $\begin{array}{l}\text { Bus } \\
\text { info }\end{array}$ & Shelters & $\begin{array}{c}\text { Improved } \\
\text { pedestrian } \\
\text { access }\end{array}$ & $\begin{array}{l}\text { Real } \\
\text { time }\end{array}$ & $\begin{array}{l}\text { Multi- } \\
\text { operator } \\
\text { integrated } \\
\text { tickets }\end{array}$ & $\begin{array}{c}\text { Reviewing } \\
\text { current } \\
\text { bus lane } \\
\text { network }\end{array}$ & $\begin{array}{l}\text { Tickets } \\
\text { bought } \\
\text { before } \\
\text { boarding }\end{array}$ & $\begin{array}{l}\text { Personal } \\
\text { security }\end{array}$ & $\begin{array}{c}\text { New } \\
\text { bus } \\
\text { lanes }\end{array}$ & $\begin{array}{l}\text { Max. } \\
\text { fares }\end{array}$ \\
\hline $\begin{array}{l}\text { To promote } \\
\text { equal access } \\
71\end{array}$ & $\begin{array}{c}67 \\
(94 \%)^{2}\end{array}$ & $\begin{array}{c}63 \\
(89 \%)\end{array}$ & $\begin{array}{c}59 \\
(83 \%)\end{array}$ & $\begin{array}{c}48 \\
(68 \%)\end{array}$ & $\begin{array}{c}35 \\
(54 \%)\end{array}$ & $\begin{array}{c}27 \\
(38 \%)\end{array}$ & $\begin{array}{c}26 \\
(37 \%)\end{array}$ & $\begin{array}{c}27 \\
(38 \%)\end{array}$ & $\begin{array}{c}23 \\
(32 \%)\end{array}$ & $\begin{array}{c}8 \\
(11 \%)\end{array}$ \\
\hline $\begin{array}{l}\text { To improve } \\
\text { the } \\
\text { environment } \\
63\end{array}$ & $\begin{array}{c}59 \\
(94 \%)\end{array}$ & $\begin{array}{c}55 \\
(87 \%)\end{array}$ & $\begin{array}{c}52 \\
(83 \%)\end{array}$ & $\begin{array}{c}42 \\
(67 \%)\end{array}$ & $\begin{array}{c}32 \\
(51 \%)\end{array}$ & $\begin{array}{c}26 \\
(41 \%)\end{array}$ & $\begin{array}{c}23 \\
(37 \%)\end{array}$ & $\begin{array}{c}19 \\
(30 \%)\end{array}$ & $\begin{array}{c}24 \\
38 \%\end{array}$ & $\begin{array}{c}8 \\
(11 \%)\end{array}$ \\
\hline $\begin{array}{l}\text { To improve } \\
\text { efficiency } 60\end{array}$ & $\begin{array}{c}56 \\
(93 \%)\end{array}$ & $\begin{array}{c}52 \\
(87 \%)\end{array}$ & $\begin{array}{c}50 \\
(83 \%)\end{array}$ & $\begin{array}{c}42 \\
(70 \%)\end{array}$ & $\begin{array}{c}29 \\
(48 \%)\end{array}$ & $\begin{array}{c}26 \\
(43 \%)\end{array}$ & $\begin{array}{c}22 \\
(37 \%)\end{array}$ & $\begin{array}{c}19 \\
(32 \%)\end{array}$ & $\begin{array}{c}23 \\
(38 \%)\end{array}$ & $\begin{array}{c}6 \\
(10 \%)\end{array}$ \\
\hline $\begin{array}{l}\text { To provide } \\
\text { opportunities } \\
57\end{array}$ & $\begin{array}{c}53 \\
(93 \%)\end{array}$ & $\begin{array}{c}47 \\
(82 \%)\end{array}$ & $\begin{array}{c}47 \\
(82 \%)\end{array}$ & $\begin{array}{c}37 \\
(65 \%)\end{array}$ & $\begin{array}{c}29 \\
(51 \%)\end{array}$ & $\begin{array}{c}21 \\
(37 \%)\end{array}$ & $\begin{array}{c}23 \\
(40 \%)\end{array}$ & $\begin{array}{c}19 \\
(33 \%)\end{array}$ & $\begin{array}{c}21 \\
(37 \%)\end{array}$ & $\begin{array}{c}6 \\
(11 \%)\end{array}$ \\
\hline $\begin{array}{l}\text { To maintain } \\
\text { infra } 56\end{array}$ & $\begin{array}{c}52 \\
(93 \%)\end{array}$ & $\begin{array}{c}49 \\
(88 \%)\end{array}$ & $\begin{array}{c}46 \\
(82 \%)\end{array}$ & $\begin{array}{c}38 \\
(68 \%)\end{array}$ & $\begin{array}{c}31 \\
(55 \%)\end{array}$ & $\begin{array}{c}23 \\
(41 \%)\end{array}$ & $\begin{array}{c}22 \\
(39 \%)\end{array}$ & $\begin{array}{c}21 \\
(38 \%)\end{array}$ & $\begin{array}{c}20 \\
(36 \%)\end{array}$ & $\begin{array}{c}7 \\
(13 \%)\end{array}$ \\
\hline $\begin{array}{l}\text { Reduce } \\
\text { greenhouse } \\
\text { gases } 47\end{array}$ & $\begin{array}{c}45 \\
(96 \%)\end{array}$ & $\begin{array}{c}40 \\
(89 \%)\end{array}$ & $\begin{array}{c}37 \\
(79 \%)\end{array}$ & $\begin{array}{c}29 \\
(62 \%)\end{array}$ & $\begin{array}{c}21 \\
(45 \%)\end{array}$ & $\begin{array}{c}17 \\
(36 \%)\end{array}$ & $\begin{array}{c}20 \\
(43 \%)\end{array}$ & $\begin{array}{c}15 \\
(32 \%)\end{array}$ & $\begin{array}{c}16 \\
(34 \%)\end{array}$ & $\begin{array}{c}6 \\
(13 \%)\end{array}$ \\
\hline $\begin{array}{l}\text { To improve } \\
\text { safety } 41\end{array}$ & $\begin{array}{c}39 \\
(95 \%)\end{array}$ & $\begin{array}{c}33 \\
(80 \%)\end{array}$ & $\begin{array}{c}34 \\
(83 \%)\end{array}$ & $\begin{array}{c}28 \\
(68 \%)\end{array}$ & $\begin{array}{c}20 \\
(49 \%)\end{array}$ & $\begin{array}{c}18 \\
(44 \%)\end{array}$ & $\begin{array}{c}18 \\
(44 \%)\end{array}$ & $\begin{array}{c}12 \\
(29 \%)\end{array}$ & $\begin{array}{c}17 \\
(41 \%)\end{array}$ & $\begin{array}{c}7 \\
(17 \%)\end{array}$ \\
\hline
\end{tabular}

$2 \%=$ percentage of those respondents who had a listed objective who chose each measure. 


\subsubsection{Policy responsibility}

This section of the survey investigated policy implementation related to the council area of each officer. The officers were first asked to indicate the number of teams within the council's transport department who have responsibility for the implementation of bus policies. The average number of teams within the council responsible for the implementation of bus policies was two. Surprisingly, 15 officers did not answer this question which could suggest they did not know whether there were such teams within the council, or perhaps they simply do not have teams within the council responsible for the implementation of bus policies. Although the survey reveals the number of teams the respondents think there are, the nature of the teams is unknown (for example, if there are separate teams for making implementing policy). Some of the confusion in the answers may arise from the fact that small authorities especially have very small staffs in transport and therefore the notion of a team only for bus policy becomes a bit artificial.

Another question in this section asked the officers for their perception of planned and actual implementation for the previous LTP/S. The majority of officers said that either most (31\%) or more than half $(45 \%)$ of the planned policies were implemented successfully. The fact that $14 \%$ of officers did not answer this question could indicate that they were not aware of success. Based on the results from the previous section, it appears that officers are more positive when asked to report on the percentage of policies implemented overall than when asked to consider specific policies and measures.

The final question in this section asked the officers if bus measures in their cities were implemented as planned and without problems. The officers agreed or strongly agreed that the bus policy measures that were implemented as planned and without problem included bus information (timetables and bus stop flags, 73\%), improved pedestrian access to stops (68\%), and quality bus stops (66\%). However, the bus policy measures that were not implemented as planned included new bus lanes (38\%), maximum fares (33\%) and multi-operator integrated tickets $(29 \%)$. This result indicates that the policy measures facing barriers are those that require collaboration and action by the operators, where the local authority has little control. In particular, multi-operator integrated ticketing has been an unattainable goal for many years, partly as a result of on-road competition; hence, operators do not view participation in such schemes to be in their best commercial interests. Furthermore, the 2008 Local Transport Act in England made multi-operator ticketing easier and more of these schemes have come into 
being. However, these are not often as a result of work by local authorities but they are instead operator initiatives. Interestingly, these results are similar to those found in the previous section where the officers were asked to state the stage at which various measures are in their city. This result clearly indicates there has been little implementation progress with certain bus measures since the last LTP/S and that certain measures that present particular implementation difficulties.

These findings suggest that there is more potential for persuading urban residents to shift mode from automobile to bus than in rural areas, which is understandable given the higher frequency and connectivity of services in urban areas.

Table 8: Bus policy measures implemented as planned and without problem

\begin{tabular}{|l|c|c|c|c|}
\hline \multicolumn{1}{|c|}{ Matrix row } & $\begin{array}{c}\text { Strongly } \\
\text { Agree }\end{array}$ & Agree & Disagree & $\begin{array}{c}\text { Strongly } \\
\text { Disagree }\end{array}$ \\
\hline $\begin{array}{l}\text { Bus Information - timetables and } \\
\text { bus stop flags }\end{array}$ & $\begin{array}{c}24 \\
(30 \%)\end{array}$ & $\begin{array}{c}34 \\
(43 \%)\end{array}$ & $\begin{array}{c}5 \\
(6 \%)\end{array}$ & $\begin{array}{c}0 \\
(0 \%)\end{array}$ \\
\hline Improved pedestrian access to stops & 18 & 36 & 9 & 0 \\
& $(23 \%)$ & $(45 \%)$ & $(11 \%)$ & $(0 \%)$ \\
\hline Quality bus stops & 13 & 40 & 3 & 0 \\
& $(16 \%)$ & $(50 \%)$ & $(4 \%)$ & $(0 \%)$ \\
\hline Multi-operatorintegrated tickets & 6 & 17 & 14 & 9 \\
& $(8 \%)$ & $(21 \%)$ & $(18 \%)$ & $(11 \%)$ \\
\hline Marketing targeted at persuading & 5 & 26 & 11 & 1 \\
regular car commuters to use public & $(6 \%)$ & $(33 \%)$ & $(14 \%)$ & $(1 \%)$ \\
transport & & & & 11 \\
\hline New bus lanes & 3 & 10 & 19 & $(14 \%)$ \\
\hline Maximum fares & $(4 \%)$ & $(13 \%)$ & $(24 \%)$ & 12 \\
& $(1 \%)$ & $(11 \%)$ & $(18 \%)$ & $(15 \%)$ \\
\hline
\end{tabular}

\subsubsection{Policy targets}

The survey included a section asking whether councils set targets and whether they were met. The results show $44 \%$ of councils met most or more than half of the targets set in the LTP/S, while $19 \%$ did not have targets related to bus policy. The results also showed that councils did not set targets for the number of vehicle kilometres per annum (74\%), fares (70\%), cost per passenger journey for services (65\%), and age and quality of vehicles (51\%). These findings show inconsistency among councils in Great Britain, and setting targets is not considered as an important aspect of the policy process. The lack of targets highlights a broken link between 
setting objectives and implementing measures to achieve them, and could even be related to political decisions not to want to identify unmet targets or may relate to the difficulty of collecting data and monitoring progress in the achievement of certain policies.

Table 9: Bus policy targets

\begin{tabular}{|l|c|c|c|}
\hline \multicolumn{1}{|c|}{ Target } & Yes & No & $\begin{array}{c}\text { We didn't } \\
\text { set a target }\end{array}$ \\
\hline Number of passengers per annum & $\begin{array}{c}13 \\
(16.3 \%)\end{array}$ & $\begin{array}{c}12 \\
(15.0 \%)\end{array}$ & $\begin{array}{c}36 \\
(45.0 \%)\end{array}$ \\
\hline Number of vehicle kilometres per annum & 2 & 1 & 59 \\
$(2.5 \%)$ & $(1.3 \%)$ & $(73.8 \%)$ \\
\hline Cost per passenger journey for services & 8 & 1 & 52 \\
& $(10.0 \%)$ & $(1.3 \%)$ & $(65.0 \%)$ \\
\hline Number of passengers satisfied with bus services & 22 & 6 & 34 \\
& $(27.5 \%)$ & $(7.5 \%)$ & $(42.5 \%)$ \\
\hline Service reliability and punctuality & 27 & 9 & 25 \\
& $(33.8 \%)$ & $(11.3 \%)$ & $(31.3 \%)$ \\
\hline Age and quality of vehicles & 17 & 3 & 41 \\
& $(21.3 \%)$ & $(3.8 \%)$ & $(51.3 \%)$ \\
\hline The things we have implemented, e.g., km of new bus & 19 & 3 & 41 \\
lanes opened, number of new shelters installed, etc. & $(23.8 \%)$ & $(3.8 \%)$ & $(51.3 \%)$ \\
\hline Fares & 4 & 1 & 56 \\
& $(5.0 \%)$ & $(1.3 \%)$ & $(70.0 \%)$ \\
\hline
\end{tabular}

\subsubsection{Performance monitoring}

The officers were asked how bus policies and measures are currently monitored by their council. The most popular form of monitoring included service reliability and punctuality (60\%), number of passengers per annum (53\%), and number of passengers satisfied with bus services $(41 \%)$. It was interesting to see continued monitoring carried out by councils given annual monitoring reports were abolished during the Local Transport Act 2008.

\subsubsection{Implementation barriers}

The last section of the survey asked the officers to identify which barriers have the greatest and least impact on implementation. The greatest barriers included the availability of resources, characteristics of local authority (e.g., competence and size of staff) and coherence and comprehensibility of the written policy. Barriers having a lower impact on implementation included public opposition, the relationship between key people in council and local bus 
operators (which does not automatically imply that a poor relationship leads to a lack of collaboration, identified earlier as a likely reason for the low level of implementation of more complex measures), and reshaping or changes to policy measures by local implementation frontline staff. A comment box also enabled the officers to identify key barriers to implementation in their council area. Comments include: "limited funding," "fierce competition between operators," "political will of members," "physical space and layout of roads," "high car ownership," and "public opinion influencing outcomes." These listed barriers, particularly lack of resources, are expected; however, the contentiousness of some local transport initiatives raises questions as to whether public opposition is one of the least important barriers. Some of the comments, moreover, may be seen to contradict the survey responses, as political will and public opinion were highlighted as important barriers. These findings provide the basis for deeper exploration through interviews with local authority officers, the findings of which are presented in the following section.

\subsection{Telephone interview results}

\subsubsection{Policy documentation}

The majority of officers interviewed said they did not have a specific bus policy document in place; yet, in response to a further question, all officers agreed that having a policy document in place important. This is an intriguing finding, considering that $74 \%$ of the survey respondents claimed to have a written policy in place, with $49 \%$ claiming to have had one for greater than 11 years. Several examples of this discrepancy were raised in the interviews. One officer believed "councils want to give the impression how well they did," while another officer thought it was a "reflection of the severe financial challenges that councils are facing now and in the future." Another officer supported both these statements by saying there was a discrepancy because "people will always say they implemented their LTP successfully because they would have made sure they spent it [funding]."

\subsubsection{Policy responsibility}

This aim of this section was to unpack why certain answers were provided in the online survey in relation to responsibility for policy implementation. Eight out of ten officers interviewed said they knew the number of teams within their council's transport department; however, two officers said they do not know or that they would not call it a "team." As mentioned in section 4.1.2, this could also indicate confusion about small authorities having very small staff numbers in transport. The next question asked the officers to consider why 15 respondents in the survey 
did not identify how many different teams were within their council's transport department. The officers suggested they "don't have the teams" or it was a combination of both answers. Three officers thought it was related to communication issues and that "people can be naïve and don't want to take responsibility." This suggests a certain level of miscommunication and indeed lack of responsibility within local authorities when it comes to bus policy implementation, which then undermines the broader process (including monitoring).

It was evident in the online survey that there were areas of concerns highlighted throughout (in terms of achieving bus policy objectives, meeting targets, and barriers related to policy implementation). The interviews revealed that the majority of officers agreed that there were inconsistencies and councils want to "give the impression how well they did." This relates to the political pressure underlying the entire policy process, from design to implementation to monitoring. A final question in this section asked the officers to comment on bus policy measures in their city. Fewer than half of the officers said they have been successful in implementing bus policy measures while three officers referred to political constraints that prevent bus policy measures being implemented as planned. This could help explain similar results found in the online survey where councils were less successful at implementing certain bus policy measures.

\subsubsection{Policy targets}

This series of questions asked the officers about the success of bus policy targets in their city. Only one council said they met all their targets while three officers said they met the majority of their targets. Reasons for not meeting targets included a "lack of communication within the council and the community" and "a lack of advertisement and marketing," which are closely related issues and essentially relate to difficulties with building public acceptability for new policy measures. When asked what more councils could do to achieve targets, three officers highlighted the need for further "financial support" to help achieve targets. However, one officer said they succeeded in their own territory, and it was the "neighbouring authority that affected the outcome of targets," while two officers said it was more of an issue with the actual targets. Other factors that are preventing councils from achieving targets include a "lack of funding" or "financial support" and "political will."

The officers were then asked if their council had policy targets. Six of the officers said they set targets in their council. In contrast to this, three officers said there was "little progress on setting 
targets since the latest LTP/S came into effect." These results could help explain why targets are not seen as an important factor as identified in the online survey. The final question in this section asked officers if targets have an impact on how policies are implemented in their city. More than half of the officers said targets have an impact. There appears to be some confusion on this topic between a recognition of the importance of targets but unclear responsibility and focus on setting and meeting them. No doubt, the political sensitivity of the topic and public accountability exert some influence in this area, but the entire policy implementation process is undermined in the absence of a clear chain from setting objectives to implementing measures to setting targets and then monitoring the outcome. Without such a framework, it becomes difficult to gauge the success of particular measures and decide on future action.

\subsubsection{Performance monitoring}

This section asked the officers if they thought it was important for monitoring to be in place to achieve bus policy success. Eight officers felt it was important; however, two officers said there should be "less concentration on bus policies" and that it was less important now because there is no funding attached. This result could indicate a concerning lack of focus on targets as a result of the decreased importance of the LTP/S, although this does not imply an abandonment of bus policies.

This section also asked the officers if more bus policy measures would be implemented as planned and without problems if stricter monitoring were in place, to which nine out of ten officers agreed. For example, one officer said it is crucial to have a "robust monitoring regime in place" because without that, "you won't be able to monitor performance." Another officer said it demonstrates that they are "achieving objectives and public money is achieving outcomes" while another said, "without robust monitoring regimes you cannot develop a sound evidence base to influence decision making." This highlights the importance of having clear strategies and tactics, rather than simply implementing policies that are "do-able." This, in turn, may improve policy development and collaboration, and promote an environment of stakeholder engagement because external stakeholders can understand the guiding logic and see evidence of progress.

Regarding the impact of funding on monitoring, one officer raised this issue by saying "council cuts" prevent putting effective monitoring in place. Similarly, another officer said monitoring is "useful for driving future funding bids. If you can prove what you have done and that it can 
be achieved...you have a good chance of continuing with your policy." This indicates that councils want monitoring in place to improve their chances of future funding to effectively monitor the measures that are in place. Again, this was an interesting result given the abolition of monitoring subsequent to the Local Transport Act 2008 and elaborates on findings in the previous sections.

\subsubsection{Implementation barriers}

The last section asked the officers to rank the greatest and least barriers to impact implementation as identified in the online survey. In line with the survey findings, eight officers ranked availability of resources (e.g., funding) as the greatest barrier to implementation in their city, while eight officers did not agree that characteristics of the local authority was one of the greatest barriers. These findings are consistent with research by McTigue et al. (2016), Preston (2016), Lindholm and Blinge (2014), Argyrioua et al. (2012) and Gaffron (2003) highlighting the difficultly that local authorities face in allocating resources to new transport policy initiatives. This is unsurprising, as lack of funding is the easiest and most natural barrier to nominate, but this does not mean that unlimited resources would ensure successful bus policy. In fact, one interviewee pointed out that "Resources is a bit of a red herring. It's important, but everyone will say that. I think you can do a lot without it. It's actually dealing with what you have got, than without." Nonetheless, undertaking a policy initiative and without financial resources to follow it through suggests poor planning.

The majority of officers did not agree that public opposition and the relationship between key people in council and local bus operators had a lesser impact on implementation. This response is in keeping with the findings across all sections of both the survey and the interviews. However, four officers agreed reshaping or changes to policy measures by local implementation frontline staff had a lesser impact. Finally, the officers were asked to comment on other barriers highlighted in the survey. About half of the officers said communication among staff involved in the policy implementation process, and motivation and attitudes of those responsible for developing or implementing bus policies were not barriers in their city. There was also considerable mention of "political will" or lack thereof as a barrier. There may seem to be some contradiction in this finding since most authorities studied appeared to have documented bus policies that had been adopted politically. However, as identified by Schade (2003), measures that get political support at a general level (e.g., there should be more bus priority) may attract much less support once they require adding a bus lane on a specific street. 


\subsection{Theoretical analysis and synthesis}

Table 10 shows the application of the hybrid theory to the two sets of data. Based on the results, each element in the framework was ranked as high, medium, or low. This is a qualitative ranking by the authors not intended for robust application but merely for ease of presenting and discussing the results. The highest impacts from both the surveys and interviews were "policy objectives," "availability of resources," "inter-organisational support and communication," and "characteristics of organisation." Both sets of data found "policy champions," "bureaucratic power," and "policy remodelling" had a lesser impact on implementation; however, there were some differences between the online surveys and telephone interviews. The online surveys highlighted "economic, social and political environments," "collaboration and interaction between those involved in the policy process," and "opposition, conflict, and ambiguities" as barriers having lesser impact on implementation, but the telephone interviews identified further key barriers associated with these variables and therefore these were ranked as having a medium impact on implementation.

From the findings, we can see the "bus policy document," "availability of resources," "interorganisational support and collaboration," and "the characteristics of the organisation" are all judged to be key factors in successful implementation. Three of these factors are in large part internal to the implementing organisation, which it must address itself if implementation is to be successful. From a STO perspective, these can be considered "tactical" issues, linking the higher level strategic aims to the operational impacts, thus suggesting that it is this link (or lack thereof) that needs the most work. Factors external to the organisation are found here to be less consistently judged by the respondents to be important, However, it is also worth noting that McTigue et al. (2016) found inter-organisational communications were not well-documented by local authorities, which limited their ability to monitor the effect of such relationships on policy implementation.

Some conflicts between the survey and interview findings likely reflect the fact that questionnaires are sometimes completed by respondents in an abstract way without linking consideration of the questions to particular cases of implementation that might have made respondents think about the issues in a more "hands-on" way. For example, it is quite surprising that "economic, social and political environments" and "opposition, conflict, and ambiguities" were judged to be less important in their influence on the implementation process than some 
other factors, as one might expect such factors to be quite critical to political support for a scheme or measure.

In terms of implications, Ballantyne et al. (2014) suggested that a generic decision-making framework would help overcome the barriers associated with the interaction between local authorities and freight stakeholders. The theoretical framework and findings of this research, as presented in Table 10, could similarly form the basis of a decision support framework for the local transport policy implementation process. 
Table 10: Theoretical analysis of online surveys and telephone interviews

\begin{tabular}{|c|c|c|c|c|}
\hline & \multirow[t]{2}{*}{ Theory } & \multicolumn{2}{|c|}{ Barriers } & \multirow[t]{2}{*}{ Impact } \\
\hline & & Online Survey & Telephone Interviews & \\
\hline 1 & $\begin{array}{l}\text { Policy } \\
\text { document }\end{array}$ & $\begin{array}{l}18 \% \text { of local authorities do not } \\
\text { have a specific bus policy } \\
\text { document in place. "Coherence and } \\
\text { comprehensibility of the written } \\
\text { policy" was identified as one of the } \\
\text { greatest barriers to } \\
\text { implementation. }\end{array}$ & $\begin{array}{l}\text { A majority of officers said they do } \\
\text { not have a specific bus policy in place. } \\
\text { All agreed it is important to have a } \\
\text { policy document in place. The } \\
\text { majority felt it was important to have } \\
\text { monitoring in place to achieve bus } \\
\text { policy measures. Policy measures } \\
\text { would be implemented as planned and } \\
\text { without problems if stricter } \\
\text { monitoring were in place. }\end{array}$ & High \\
\hline 2 & $\begin{array}{l}\text { Availability of } \\
\text { resources }\end{array}$ & $\begin{array}{l}\text { Ranked as the greatest barrier to } \\
\text { implementation. } \\
\text { funding" identified as a key barrier. }\end{array}$ & $\begin{array}{l}\text { Ranked the greatest barrier to impact } \\
\text { implementation. Lack of resources } \\
\text { prevented councils meeting targets. }\end{array}$ & High \\
\hline 3 & $\begin{array}{l}\text { Inter- } \\
\text { organisation } \\
\text { support and } \\
\text { communication }\end{array}$ & $\begin{array}{l}\text { Ranked fourth highest barrier to } \\
\text { implementation. }\end{array}$ & $\begin{array}{l}\text { Half of the officers said } \\
\text { communication was a barrier to } \\
\text { implementation. Communication } \\
\text { barriers highlighted between } \\
\text { neighbouring authorities, bus } \\
\text { operators, stakeholders, politicians } \\
\text { and the general public. }\end{array}$ & High \\
\hline 4 & $\begin{array}{l}\text { Characteristics } \\
\text { of organisation }\end{array}$ & $\begin{array}{l}\text { Ranked as the second highest } \\
\text { barrier to implementation. } 15 \\
\text { officers could not indicate the } \\
\text { number of teams within the } \\
\text { council's transport department who } \\
\text { have responsibility for the } \\
\text { implementation of bus policies. }\end{array}$ & $\begin{array}{l}\text { A majority of officers did not agree } \\
\text { this was one of the greatest barriers. } \\
\text { But staffing difficulties such as } \\
\text { shortage of staff or over-worked staff } \\
\text { was raised on several occasions. Two } \\
\text { officers did not know the number of } \\
\text { teams responsible for implementation } \\
\text { of bus policies. }\end{array}$ & High \\
\hline 5 & $\begin{array}{l}\text { Economic, } \\
\text { social and } \\
\text { political } \\
\text { environments }\end{array}$ & $\begin{array}{l}\text { Officers identified key barriers in } \\
\text { their area as "bus wars between } \\
\text { operators"; "political will of } \\
\text { members"; "physical space and } \\
\text { layout of roads" and "high car } \\
\text { ownership." }\end{array}$ & $\begin{array}{l}\text { Barriers include political constraints } \\
\text { and support, the impact of } \\
\text { neighbouring authorities, current } \\
\text { economic climate and public } \\
\text { opposition. }\end{array}$ & Medium \\
\hline 6 & $\begin{array}{l}\text { Policy } \\
\text { champions }\end{array}$ & $\begin{array}{l}\text { Ranked as having a lesser impact } \\
\text { on implementation. }\end{array}$ & $\begin{array}{l}\text { Four officers did not agree with the } \\
\text { survey that this had a lesser impact on } \\
\text { implementation. }\end{array}$ & Low \\
\hline 7 & $\begin{array}{l}\text { Bureaucratic } \\
\text { power }\end{array}$ & $\begin{array}{l}\text { Ranked as having a lesser impact } \\
\text { on implementation. }\end{array}$ & $\begin{array}{l}\text { Three officers did not agree with the } \\
\text { survey that this had a lesser impact on } \\
\text { implementation. }\end{array}$ & Low \\
\hline
\end{tabular}




\begin{tabular}{|c|c|c|c|c|}
\hline 8 & $\begin{array}{l}\text { Collaboration } \\
\text { and interaction } \\
\text { between those } \\
\text { involved in the } \\
\text { policy process }\end{array}$ & $\begin{array}{l}\text { Ranked as having a lesser impact } \\
\text { on implementation. }\end{array}$ & $\begin{array}{l}\text { A majority of officers highlighted the } \\
\text { importance of the interaction between } \\
\text { the councils and bus operators and felt } \\
\text { it was "key" to have "a good strong } \\
\text { partnership arrangement" }\end{array}$ & Medium \\
\hline 9 & $\begin{array}{l}\text { Policy } \\
\text { remodelling }\end{array}$ & $\begin{array}{l}\text { Ranked as having a lesser impact } \\
\text { on implementation. }\end{array}$ & $\begin{array}{l}\text { One officer said policy change } \\
\text { prevented their council implementing } \\
\text { particular policy measures. Another } \\
\text { officer said partners and stakeholder } \\
\text { working groups are key so that policy } \\
\text { does not change during } \\
\text { implementation. }\end{array}$ & Low \\
\hline 10 & $\begin{array}{l}\text { Opposition, } \\
\text { conflict, and } \\
\text { ambiguities }\end{array}$ & $\begin{array}{l}\text { Ranked as having a lesser impact } \\
\text { on implementation. Some officers } \\
\text { identified key barriers in their area } \\
\text { as "bus wars between operators," } \\
\text { "public opinion influencing } \\
\text { outcomes." }\end{array}$ & $\begin{array}{l}\text { Barriers include conflict and } \\
\text { ambiguities between councils and the } \\
\text { general public, local bus operators } \\
\text { who competed with each other, and } \\
\text { neighbouring councils who were } \\
\text { fighting amongst each other for } \\
\text { budgets. }\end{array}$ & Medium \\
\hline
\end{tabular}

\section{Conclusions}

This research investigated barriers to the implementation of bus policies by local authorities in Great Britain. Analysis of the online surveys and telephone interviews using the hybrid theory revealed four barriers to have a particularly high impact on implementation. Both the online survey and interviews ranked the availability of resources as the greatest barrier to implementation. The interviews revealed that a lack of funding was preventing councils from achieving targets and there was a need for further financial support to help achieve targets. Therefore, authorities must be certain from the planning stage that there are sufficient resources available to support the initiative once implemented. Also, a lack of financial support could also be linked to a lack of political support during the implementation stage to access the required funds.

Both sets of data identified problems associated with current bus policy documentation. This was noticeable where $18 \%$ of the officers from the online survey and the majority of officers interviewed did not have a specific bus policy document in place. However, it was interesting to see all officers interviewed expressed the importance of this document. Other concerns over 
the coherence and comprehensibility of the policy include achieving the objectives set in the written policy document.

Although the survey results reveal that councils are setting objectives, there were many areas of concern highlighted throughout the survey in terms of setting targets and implementing measures to achieve these objectives. The interviews showed that more than half of the officers believed targets have an impact on how policies are implemented in their city, but concerns were expressed that either targets were not set or were not monitored. This is consistent with the finding by Van de Velde and Wallis (2013) that success is dependent upon the co-existence of a policy environment generally supportive of public transport. Thus, while the case presented here must be understood within the specific regulatory context of public transport in Britain outside London, the lessons summarised in Table 10 remain generalizable in terms of the need for a supportive and coherent policy framework for successful policy implementation.

Another high-impact barrier, inter-organisational support, and communication, was ranked fourth in the online survey, while the telephone interviews revealed that there were concerns in some councils over the communication between neighbouring authorities, bus operators, stakeholders, politicians, and the general public. It is evident that communication and cooperation are essential for successful implementation, which is also recognised by policymakers. For example, the Scottish Government (2005) reported that local bus networks are more likely to be successful if there is "a close working partnership between the local authority and the bus operators."

A final high-impact barrier to implementation found in this study concerned the characteristics of the organisation, although there were some discrepancies on this point. The surveys ranked this second, while the interview respondents did not explicitly rate this as one of the greatest barriers. However, staffing difficulties, such as shortage of staff or over-worked staff, were raised several times. This is consistent with the finding of De Gruyter et al. (2015) that the "uncertainty over implementation responsibilities" a "general lack of ownership" can have a negative impact on implementing travel plans. The related finding of Ison and Rye (2003) that a "policy champion," "political stability," and "trust in terms of the parties' involved" are needed for successful policy implementation was not explicitly recognized here, but did come through in the comments regarding a lack of financial support from politicians to implement the policies that they have set. 
Barriers that were highlighted as having a medium impact on implementation were associated with economic, social, and political environments; collaboration and interaction between those involved in the policy process; and opposition, conflict, and ambiguities. These were identified as a lesser impact in the online surveys but higher in the interviews, which may be indicative of the more abstract nature of the questionnaire as compared to the real-world experience of the interviewees, which also highlights the importance of complementary research methods.

In terms of how it might be applied, the ten-point framework used here is not limited to bus policy and could also be applied to policy affecting other transport modes, such as walking, cycling, freight, parking, etc. The findings from this research can inform policymakers, local authority staff, regional transport partnerships, bus operating companies, and other practitioners working in local transport policy, in Great Britain and elsewhere.

This research has identified several concerns with bus policy implementation. The most obvious concern is the unclear link among policy objectives and measures and the setting and monitoring of performance targets, which appears to stem in part from the lack of a tactical link between the higher level strategic objectives and the operational aspects of policy implementation. One reason for this may be the over-emphasis on the availability of resources, which is seen as the greatest barrier to implementation based on several references made throughout the surveys and interviews. This unclear link indicates that councils are in fact placing too much emphasis on "what" is needed to implement policy (i.e., resources) and instead they should be placing more emphasis on "how" to implement the policy in terms of targets, measures, and performance monitoring. Once this is clear, councils can then direct resources where needed.

The overall conclusion of the research highlights the relationship between policy design and policy implementation in meeting transport policy objectives. Moreover, it is essential to regularly monitor performance in meeting specified targets. The deregulation of the bus sector in the UK means that in some cases, a lack of control over the implementation of certain measures places limits on successful policy implementation and results in the frequent implementation of policy measures that are achievable rather than those that necessary to the successful achievement of policy objectives. 


\section{References}

Argyriou, I., Fleming, P., and Wright, A., 2012. Local climate policy: Lessons from a case study of transfer of expertise between UK local authorities. Sustainable Cities and Society, 5(2012), pp. 87-95.

Ballantyne, E.E., Lindholm, M., Whiteing, A., 2013. A comparative study of urban freight transport planning: addressing stakeholder needs. Journal of transport geography, 32, pp. 93-101.

Banister, D., 2000. Sustainable mobility. In: Built Environment, 26(3), pp. 175-186.

De Gruyter, C., Rose, G., Currie, G., 2015. Enhancing the impact of travel plans for new residential developments: Insights from implementation theory. Transport policy, 40, pp. 24-35.

Department for Transport, 2016. Annual bus statistics England 2015/16. Department for Transport, London, UK.

Elmore, R. F., 1980. Backward Mapping. Implementation Research and Policy Decisions. Political Science Quarterly 94(4), pp. 601-616.

Gaffron, P., 2003. The implementation of walking and cycling policies in British local authorities. Transport policy, 10(3), pp.235-244.

Gössling, S., Cohen, S.A., Hares, A., 2016. Inside the black box: EU policy officers' perspectives on transport and climate change mitigation. Journal of Transport Geography, 57, pp.83-93.

Grindle, M., Thomas, J., 1990. After the Decision: Implementing Policy Reforms in Developing Countries. World Development, 18(8).

Gunn, L, A., 1978. Why is implementation so difficult? Management Services in Government 33, pp. 169-176.

Hjern, B., Hanf, K., Porter, D., 1978. Local Networks of Manpower Training in the Federal Republic of Germany and Sweden. In Interorganizational Policy Making: Limits to Coordination and Central Control, Sage, London, pp. 303-44.

Ison, S., Rye, T., 2003. Lessons from travel planning and road user charging for policy-making: through imperfection to implementation. Transport Policy, 10(3), pp. 223-233.

Lindholm, M.E., Blinge, M., 2014. Assessing knowledge and awareness of the sustainable urban freight transport among Swedish local authority policy planners. Transport policy, 32, pp.124-131.

Lipsky, M., 1971. Street Level Bureaucracy and the Analysis of Urban Reform. Urban Affairs Review 6, pp. 391-409. 
Lipsky, M., 1980. Street-level bureaucracy: Dilemmas of the individual in public services. New York: Russell Sage Foundation.

Marshall, C., and Rossman, B., G., 1999. Designing qualitative research. 3rd ed. London: Sage Publications.

Matland, R., 1995. Synthesising the implementation literature: the ambiguity-conflict model of policy implementation. Journal of Public Administration Research and Theory 5(2), 145 174.

McConville, J. ed., 1997. Transport regulation matters. A\&C Black.

McTigue, C., Rye, T., Monios, J., 2016. The role of reporting mechanisms in transport policy implementation by local authorities in England. In: Proceedings of the World Conference on Transportation Research. Shanghai, China, July 2016.

Pateman, T., 2011. Rural and urban areas: comparing lives using rural/urban classifications. Regional Trends, 43(1), pp.11-86.

Pressman, J., Wildavsky, A., 1973. Implementation: How Great Expectations in Washington are dashed in Oakland, Berkeley. University of California Press.

Preston, J., 2016. Big buses in a small country: The prospects for bus services in Wales. Research in Transportation Economics, 59(2016), 379-387.

Preston, J., Almutairi, T., 2016. Evaluating the long term impacts of transport policy: The case of bus deregulation revisited. Research in Transportation Economics, 48(2014) 263-269.

Rein, M., 1983. Action frames and problem setting. From policy to practice, London: Macmillan, pp. 221-234.

Sabatier, P., Mazmanian, D., 1981. The Implementation of Public Policy: A Framework of Analysis In: Mazmanian, D., Sabatier, P. (Eds.) Effective Policy Implementation. D.C. Health and Company, US.

Schade, J., 2003, European research results on transport pricing acceptability. In: Acceptability of transport pricing strategies, edited by Schade, J. and Schlag, B. (Oxford, U.K.: Elsevier), pp. 109-124

Scottish Government, 2005. Scotland's Transport Future: Guidance on Local Transport Strategies. Scottish Government, UK.

Spear, J., Lightowler, A., 2005. Delivering Local Transport Strategies in Scotland - Are Lessons to be Learnt from English Local Transport Plans?. STAR Conference, Glasgow. Available: http://www.starconference.org.uk/star/2005/andy_lightowler.pdf

Transport Scotland, 2016. Scottish Transport Statistics No 342015 Edition. Transport Scotland, UK. 
Urban Transport Group, 2016. Bus Policy Briefing 2016. Version 8: June 2016.

Van de Velde, D. and Augustin, K., 2014. Workshop 4 Report: Governance, ownership and competition in deregulated public transport markets. Research in Transportation Economics, 48, pp.237-244.

Van de Velde, D. and Wallis, I., 2013. 'Regulated deregulation' of local bus services-An appraisal of international developments. Research in Transportation Economics, 39(1), pp.2133.

Van Meter, D., Van Horn, C., 1975. The Policy Implementation Process: A Conceptual Framework. Administration \& Society 6(4), 445-487.

Welsh Government, 2016. Public service vehicles in Wales, 2014-15. Welsh Government, UK White, P., 1995. Deregulation of local bus services in Great Britain: an introductory review. Transport Reviews, 15(2), pp.185-209.

White, P.R., 1997. What conclusions can be drawn about bus deregulation in Britain?. Transport Reviews, 17(1), pp.1-16.

White, P.R., 2010. The conflict between competition policy and the wider role of the local bus industry in Britain. Research in Transportation Economics, 29(1), pp.152-158.

Wickramasinghe, N., 2016. Handbook of Research on Healthcare Administration and Management. IGI Global. 